\title{
Understanding Wellbeing and Devolution in Scotland, Wales and Northern Ireland
}

\begin{abstract}
Wallace provides an overview of the responsibilities of the devolved legislatures of Scotland, Wales and Northern Ireland and how these have developed over the past 20 years. Key facts on each jurisdiction are set out as are the trends in wellbeing. Wellbeing in each devolved jurisdiction is compared to the rest of the UK and the OECD regions to provide insight into the issues facing each jurisdiction. Wallace concludes with a discussion of mechanisms for assessing policy impact, noting in particular the importance of viewing governments impact on wellbeing as contribution not attribution.
\end{abstract}

Keywords Devolution - Key facts - Social indicators - Policy impact

\section{Understanding Devolution}

Devolution is a process, not an event.

Ron Davis, Secretary of State for Wales

(Institute of Welsh Affairs 1998)

Any study of devolved policy-making in the UK has to start from the basis that the systems of devolution implemented in the 1990s and 2000 s are asymmetric, differing from each other in a number of important ways and each having a unique constitutional history:

(C) The Author(s) 2019

J. Wallace, Wellbeing and Devolution, Wellbeing in Politics and Policy, https://doi.org/10.1007/978-3-030-02230-3_2 
Asymmetry runs through every clause and schedule of the devolution legislation, from the fundamentals of powers and functions down to the niceties of nomenclature... These are not accidental choices... they are deliberate differences chosen to emphasise the difference in style and substance between the three devolved assemblies, and in particular between each of the devolved assemblies and their parent body at Westminster. (Hazell 2000, p. 269)

It is common to talk of devolution leading to divergence but this is to misunderstand the relationships between the constituent parts of the UK prior to devolution-presupposing an earlier state when the approaches were convergent. But Scotland, Wales and Northern Ireland had administrative devolution long before they had legislatures (Greer and Jarman 2008). There never was one UK National Health Service, for example: the Scottish NHS was always a separate entity managed by the Scottish Office. Legislation for Scotland and Northern Ireland on key public services was separate, passed in Westminster Parliament when parliamentary time allowed for it.

To different extents, there are also separate professional groups in the devolved administrations. Elite professional communities around health, education and local government managed public services through partnership prior to devolution and were heavily respected actors not consultees or stakeholders. Policy-making was largely managed through consensus between these groups in the devolved administrations rather than led by political think tanks competing for space with new ideas (Greer and Jarman 2008).

The constituent parts of the UK have always proudly exhibited difference in policy and its implementation. Devolution has given a new tier of democracy, and new powers to act locally, but each devolved administration has had to establish itself within the previous policy community. They did not emerge from a vacuum.

Table 2.1 presents key similarities and differences between the administrations. Each was established (or re-established) in the New Labour era; each has an electoral system favouring proportional representation; each has a system of unitary local authorities and each has sought to carve out their approach to wellbeing over the past decades. But the discourse on wellbeing in each jurisdiction differs significantly. The extent to which there are common attributes and shared learning is a key question for the remainder of the book. 


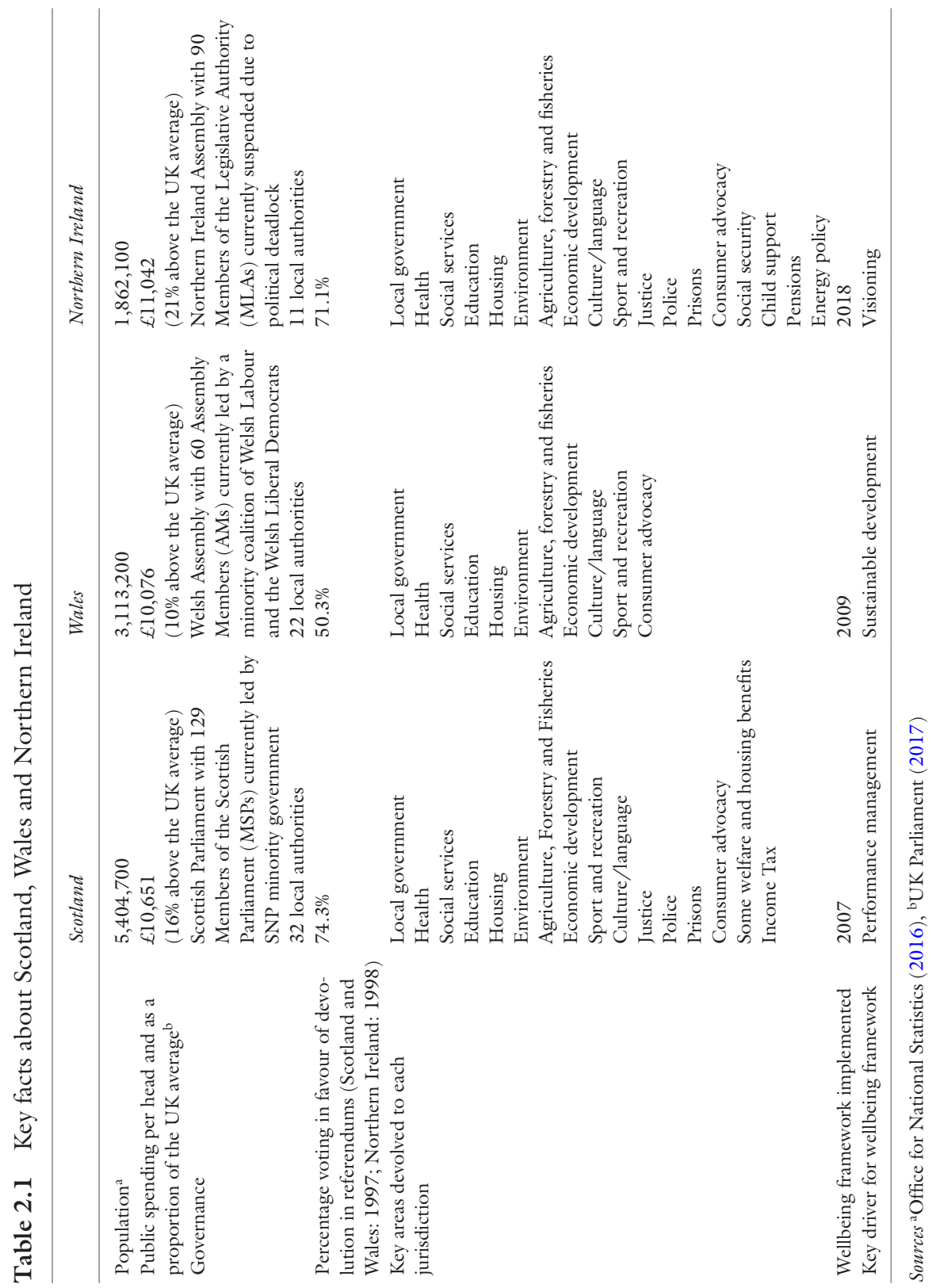


The powers of the three devolved administrations have become more similar over time. The Northern Ireland Assembly originally had limited powers over justice. These powers were increased following the Hillsborough Castle Agreement in 2010 which resulted in it taking responsibility for: criminal law, policing, prosecution, public order, courts, prisons and probation (Northern Ireland Office 2010). In terms of social security, formally, the Northern Ireland Assembly also has responsibility for social security, child support and pensions but, in practice, follows policy set by the Westminster Parliament to provide consistency across the UK.

Scotland increased its powers through the Scotland Act 2016. The Act gives extra powers to the Scottish Parliament and a Scottish Government including:

- The ability to amend sections of the Scotland Act 1998 which relate to the operation of the Scottish Parliament and the Scottish Government within the UK including control of its electoral system (subject to a two-thirds majority within the parliament for any proposed change).

- Legislative control over areas such as road signs, speed limits, onshore oil and gas extraction, rail franchising, consumer advocacy and advice among others by devolution of powers in relation to these fields to the Scottish Parliament and the Scottish Ministers.

- Management of the Crown Estate, the British Transport Police and Ofcom in Scotland.

- Control over Air Passenger Duty and Aggregates Levy.

- Control over certain aspects of several welfare and housing-related benefits and Disability Living Allowance, Personal Independence Payment, Attendance Allowance and Carer's Allowance.

- The ability to set Income Tax rates and bands on non-savings and non-dividend income.

- Extended powers over Employment Support and Universal Credit.

- The right to receive half of the VAT raised in Scotland.

Wales has also been on a significant constitutional journey. The Government of Wales Act 2006 introduced primary legislative powers for the first time. The Wales Act 2014 conferred tax-raising powers followed by the Wales Act 2017 which gave extra powers to the National Assembly for Wales and the Welsh Government including: 
- The ability to amend sections of the Government of Wales Act 2006 which relate to the operation of the National Assembly for Wales and the Welsh Government within the UK, including control of its electoral system (subject to a two-thirds majority within the Assembly for any proposed change).

- Legislative control over areas such as road signs, speed limits, onshore oil and gas extraction, harbours, rail franchising, consumer advocacy and advice.

- Management of Ofcom in Wales.

The Wales Act 2017 recognised the National Assembly for Wales and the Welsh Government as permanent among the UK's constitutional arrangements, with a referendum required before either can be abolished. The changes also moved Wales from a conferred matters model to a reserved matters model, which is used in Scotland and means that the Assembly is assumed to have legislative competence unless an area of law is formally reserved to the UK Government. The legislation however stopped short of providing Wales with the control given to Scotland over tax and benefits.

Within EU structures, the UK's three devolved jurisdictions are 'legislative regions' less than full member states but recognised as more powerful than regional or local authorities. Other EU countries with legislative regions include Germany, Spain, Italy, Austria and Belgium. These second-tier governments have primary legislative responsibility for key areas of government, often focused on social policy, but with some also holding economic and security powers.

Despite this formal status however, they fit somewhat awkwardly into international analysis. For example, the OECD How's Life in Your Region programme includes Wales, Scotland and Northern Ireland as regions (OECD 2016a). The OECD classifies regions as the first administrative tier of sub-national government (e.g. States in the United States, Provinces in Canada, or Régions in France) (OECD 2016b). It then goes on to sidestep the issue by referring to the $12 \mathrm{UK}$ administrative areas as 'countries or regions'.

\section{Trends on Wellbeing in Wales, Scotland AND NorTHERN IRELAND}

While the OECD highlights the importance of improving the availability of data at regional level (OECD 2013), this is a minority issue within the UK devolved legislatures-all have access to relatively rich datasets from 
official statistics. The issues faced by the devolved administrations, as we will see in later chapters, have far more in common with those from nation-states with a strong focus on putting wellbeing into policy practice (Wallace and Schmueker 2012).

However, comparative data can be problematic. Each wellbeing framework differs in the measures used and as such there is no direct comparison between their own indicator sets. Table 2.2 uses data from How's Life in Your Region to provide comparisons within the UK and internationally with the OECD regions. This gives some insight into the generic and specific issues faced by the jurisdictions. I present this with some caution: these are the best comparative figures, but they are not the ones used by the devolved governments to hold themselves to account through wellbeing frameworks. ONS data from the Measuring National Wellbeing programme could also have been used to identify key issues within the UK. I selected OECD data for this analysis to provide an international comparison.

The comparative data shows the similarities and differences in the social issues facing each jurisdiction. All three jurisdictions perform well on indicators of community (having a strong social network), access to broadband and the environmental indicator (air quality). They perform less well on health outcomes, with Scotland and Wales comparing poorly with other UK regions and overall around the middle of the ranking for OECD regions.

Compared to the 12 UK regions, Wales, Scotland and Northern Ireland experience relatively low income levels (though Scotland is notably higher), but compared to OECD regions as a whole they perform around the middle of the rank. Aligned to this, Scotland and Wales perform around the middle of OECD regions on employment, with Northern Ireland coming towards the bottom of the rank.

Northern Ireland also fares worse on indicators of education and democracy than Wales and Scotland, but it performs slightly better on the environmental indicator. Wales is the safest of the three jurisdictions, measured by number of homicides. But overall life satisfaction is slightly higher in Scotland and Northern Ireland than it is in Wales.

This brief description shows the difficulties in using wellbeing dashboards as comparative measures. Firstly, the international datasets use rather crude measures. Level of homicides may be comparable, but it is not the measure used in the three jurisdictions to assess safety (where both perceptions of crime and the crime rate are used). Secondly, as the 


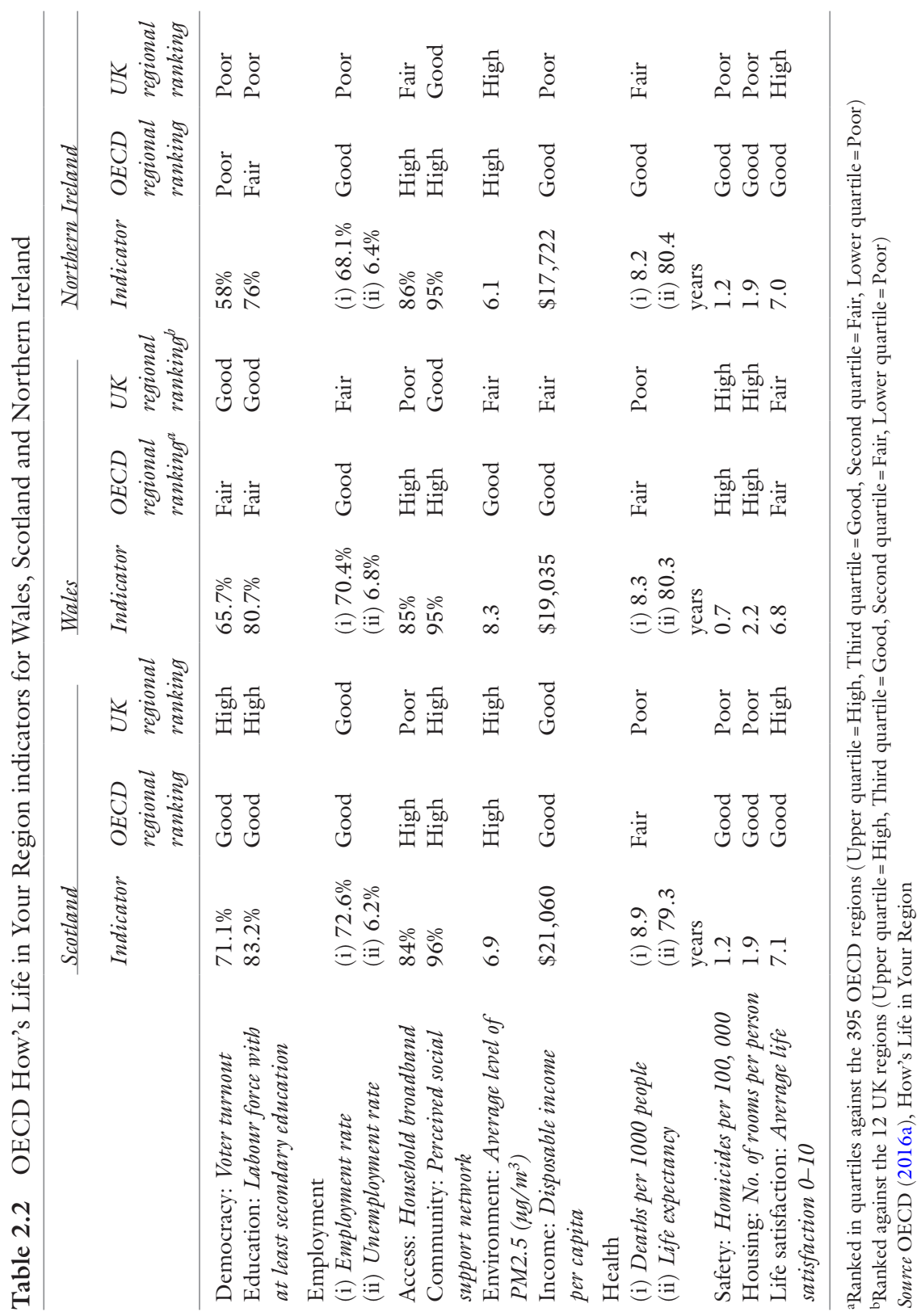


indicators cluster around norms in developed welfare states, relatively small changes can have large impacts on the rankings, for example, a 2\% difference in the employment rate pushes Northern Ireland to the bottom quartile of the OECD regional rank. And finally, the comparative data can only be seen as the start of a process of policy analysis, not a substitute for it. The only reasonable response to such data can be 'why is that the case?'

\section{Understanding Policy Impact from a Wellbeing Perspective}

In Chapters 3, 4 and 5 the process of developing and implementing the wellbeing framework is described and an assessment of policy impact is made. Chapter 6 discusses the overall comparative analysis and what we can begin to say about the use of wellbeing frameworks as a tool to transform government.

In making the assessment of policy impact, I had access to the perspectives of experts in each of the jurisdictions, written and oral evidence submitted to the Governments and Parliaments/Assembly, parliamentary debates and analysis of written policy reports.

The analysis brought together these evidence sources, and those impacts reported on are the ones that are shared by more than one stakeholder or data source in each of the jurisdictions. Too often policymaking is seen, and described, as a 'black box' which is impenetrable from the outside. To shed more light, I use a categorisation of impact developed by the Annie E Casey Foundation in the USA (see Table 2.3). This separates out advocacy change, policy change and social change, avoiding the conflation of one with the other which is all too common in analysis (Organizational Research Services 2007).

This categorisation is particularly relevant for an analysis of wellbeing frameworks as the evidence suggests they operate at all three levels:

- They seek a change in the narrative and understanding of social progress away from economic dominance towards a multidimensional approach.

- They aim to have a discernible impact on policy-making to ensure decisions are made that are based on assessment of impacts across all domains of wellbeing.

- Through the above, they aim to improve outcomes for citizens across the range of wellbeing domains. 
Table 2.3 Impact categorisation

\begin{tabular}{lll}
\hline Advocacy change & Policy change & Social change \\
\hline $\begin{array}{l}\text { Evidence of changes in } \\
\text { understanding and support } \\
\text { for an issue }\end{array}$ & $\begin{array}{l}\text { Evidence of changes in } \\
\text { policy development and } \\
\text { implementation }\end{array}$ & $\begin{array}{l}\text { Evidence of large-scale } \\
\text { societal change }\end{array}$ \\
$\begin{array}{l}\text { Advocacy change aims to } \\
\text { provide the essential } \\
\text { infrastructure that leads to } \\
\text { policy change and } \\
\begin{array}{l}\text { subsequently to social } \\
\text { change }\end{array}\end{array}$ & $\begin{array}{l}\text { islation, regulations, guidance, } \\
\text { funding) aim to improve how } \\
\text { goods and services are delivered } \\
\text { to achieve specific outcomes for } \\
\text { citizens }\end{array}$ & $\begin{array}{l}\text { Often relies on policy } \\
\text { and advocacy change but } \\
\text { has a real-world impact, } \\
\text { statics }\end{array}$ \\
\hline
\end{tabular}

Source Annie E Casey Foundation (2007)

Policy analysis is often carried out to determine if the programme intervention was indeed responsible for any social changes. But seeking to establish causality or attribution can be extremely difficult and often misleading. The approach taken is therefore to seek contribution analysis which provides 'not definitive proof, but rather provides evidence and a line of reasoning from which we can draw a plausible conclusion that, within some level of confidence, the program has made an important contribution to the documented result' (Better Evaluation, online). The Scottish Government explicitly uses contribution analysis to understand the impact of the National Performance Framework (Scottish Government 2011).

The intention is therefore not to prove a particular outcome from wellbeing frameworks but rather to explore the contribution that the frameworks have made to policy-making by exploring the available evidence. The theory of change developed is that the wellbeing framework contributes to a wellbeing approach to government activity, which in turn improves social outcomes. In compiling this analysis, my aim has been to tell a story of the development and implementation of wellbeing frameworks in such a way as to can draw tentative but credible conclusions about the contribution made to advocacy, policy and social change in the three jurisdictions. 


\section{REFERENCES}

Better Evaluation, online. Better Evaluation. Available at: http://betterevaluation.org/plan/approach/contribution_analysi. Accessed June 2018.

Greer, S. L., \& Jarman, H. (2008). Policy Styles and Devolution. In A. Trench (Ed.), The State of the Nations 2008 (pp. 167-197). Exeter: Imprint Academic.

Hazell, R. (2000). The State and the Nations: The First Year of Devolution in the United Kingdom. Thorverton: Imprint Academic.

Institute of Welsh Affairs. (1998). Devolution is a Process, Not an Event. Cardiff: Institute of Welsh Affairs.

Northern Ireland Office. (2010). Hillsborough Castle Agreement [Online]. Available at: https://www.gov.uk/government/publications/hillsborough-castle-agreement. Accessed Feb 2018.

OECD. (2013). OECD Regions at a Glance. Paris: OECD.

OECD. (2016a). OECD Regions at a Glance [Online]. Available at: http://www. oecd-ilibrary.org/governance/oecd-regions-at-a-glance-2016_reg_glance2016-en. Accessed Feb 2018.

OECD. (2016b). Regional Wellbeing User Guide. Paris: OECD.

Office for National Statistics. (2016). Mid-year Population Estimates [Online]. Available at: https://www.ons.gov.uk/peoplepopulationandcommunity/populationandmigration/populationestimates/bulletins/annualmidyearpopulationestimates/latest. Accessed Jan 2018.

Organizational Research Services. (2007). A Guide to Measuring Advocacy and Policy Annie E Casey Foundation. Baltimore, MD: Organizational Research Services.

Scottish Government. (2011). Contribution Analysis. Edinburgh: Scottish Government.

UK Parliament. (2017). Research Briefing: Public Spending by Country and Region [Online]. Available at: http://researchbriefings.parliament.uk/ ResearchBriefing/Summary/SN04033. Accessed Aug 2018.

Wallace, J., \& Schmueker, K. (2012). Shifting the Dial: From Wellbeing Measures to Policy Practice. Dunfermline: Carnegie UK Trust. 
Open Access This chapter is licensed under the terms of the Creative Commons Attribution 4.0 International License (http://creativecommons.org/licenses/ by $/ 4.0 /$ ), which permits use, sharing, adaptation, distribution and reproduction in any medium or format, as long as you give appropriate credit to the original author(s) and the source, provide a link to the Creative Commons license and indicate if changes were made.

The images or other third party material in this chapter are included in the chapter's Creative Commons license, unless indicated otherwise in a credit line to the material. If material is not included in the chapter's Creative Commons license and your intended use is not permitted by statutory regulation or exceeds the permitted use, you will need to obtain permission directly from the copyright holder.

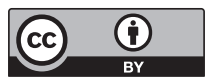

